Limnological Review (2010) 10, 1: 15-21

DOI 10.2478/v10194-011-0002-8

\title{
Methane and carbon dioxide emission from some reservoirs in SE Poland
}

\author{
Renata Gruca-Rokosz ${ }^{*}$ Janusz A. Tomaszek, Piotr Koszelnik, Ewa Czerwieniec
}

Rzeszów University of Technology, Faculty of Civil and Environmental Engineering, Department of Environmental and Chemistry Engineering, W. Pola 2, 37-959 Rzeszów, Poland, e-mail: renatagr@prz.rzeszow.pl

\begin{abstract}
The results of emission measurements of carbon dioxide and methane from the surfaces of three man-made lakes in southeastern Poland (two little dam reservoirs - in Rzeszów and Wilcza Wola, and the biggest Polish reservoir situated in Solina) are presented in this paper. The experiments were conducted in summer and autumn of 2009. The gas fluxes on the water - atmosphere interface were measured in the littoral area by so called "static chamber" method. Carbon dioxide and methane concentrations in collected gas samples were measured using a Pye Unicam gas chromatograph (model PU-4410/19) equipped with a methanizer to detect low levels of $\mathrm{CO}_{2}$ concentrations. The fluxes of determined gases ranged from -24.98 to $162.51 \mathrm{mmol} \mathrm{m}^{-2} \mathrm{~d}^{-1}$ for carbon dioxide and from 0 to $235.60 \mathrm{mmol}$ $\mathrm{m}^{-2} \mathrm{~d}^{-1}$ for methane. The highest values of flux for both $\mathrm{CH}_{4}$ and $\mathrm{CO}_{2}$ were observed for Rzeszów Reservoir, the lowest ones - for Solina Reservoir. In some studied cases emission of $\mathrm{CO}_{2}$ and $\mathrm{CH}_{4}$ was as much high as in tropical reservoirs.
\end{abstract}

Key words: methane, carbon dioxide, greenhouse gases, sediment, reservoir

\section{Introduction}

Observations of global climatic warming in recent years have tended to stimulate work seeking to study emissions of the so-called "greenhouse gases" to the atmosphere, from both aquatic and terrestrial environments (Adams and Baudo 2001; Rastogi et al. 2002; Haese et al. 2003; Adams 2005; Matthews et al. 2005; Søvik et al. 2007; Wilcock and Sorrell 2008).

Excessive carbon dioxide and methane emissions are considered the main reason for observed enhancement of the greenhouse effect. Although the methane concentration is much lower than that of carbon dioxide, the latter's global warming potential (GWP) is more than twenty times as great. Thus, a further increase in the atmospheric concentrations of either of these gases may have serious global climatic consequences.

While the oceans undoubtedly play a key role in global gaseous exchange processes, there are grounds for believing that continental waters (and in fact lakes of anthropogenic origin in particular) may play a role disproportionate to their area in global greenhouse gas dynamics. Considerable areas of land have been and are being flooded as dam reservoirs are completed, the result being the decay of labile organic matter and consequent greenhouse gas emissions. It was originally felt that such gas emissions diminish over time overall, but this opinion has yet to be verified thoroughly. Indeed, it is currently considered plausible that the immediate and major post-flooding emission of gases gives way to emissions at a relatively steady level during the entire lifetime of a given reservoir. Thus dam reservoir construction can have a great influence on the production of greenhouse gases and their release to the atmosphere. Preliminary calculations indicate that $\mathrm{CO}_{2}$ and $\mathrm{CH}_{4}$ emission from reservoirs may in fact constitute up to $7 \%$ of all anthropogenic emission of these gases to the atmosphere (St. Louis et al. 2000).

The aim of the work described here has thus been to calculate the $\mathrm{CO}_{2}$ and $\mathrm{CH}_{4}$ fluxes to the atmosphere from three dam reservoirs in south-eastern Poland. 


\section{Methods}

\section{Study site description}

The study sites, comprising two small reservoirs (Wilcza Wola and Rzeszów) and one large hydroelectric reservoir (Solina), are located in south-eastern Poland (Fig. 1). Characteristics of these reservoirs are as presented in Table 1.

The Solina Reservoir, Poland's largest manmade lake, is situated on the San River in the Bieszczady Mountains. It accounts for some $15 \%$ of overall water storage in Poland. Filled in 1968, it was initially used to generate power, but later also became a source of water supply and a recreation centre. Apart from its natural tributaries, the Solina Reservoir is supplied by the double rotation turbines of a power plant situated in the low-lying Myczkowce stilling basin. Economic activity in the reservoir's watershed is limited. The main part of the basin is occupied by forests, and only to a lesser extent by meadows and pastures. The drainage basin is sparsely populated. Farmed agricultural land and settlements are mainly located at the mouths of the tributary valleys.

Constructed in 1973, the Rzeszów Reservoir is located on the River Wisłok in SE Poland. After 20 years of exploitation, its water volume has decreased considerably, with fast growth of aquatic plants ensur-

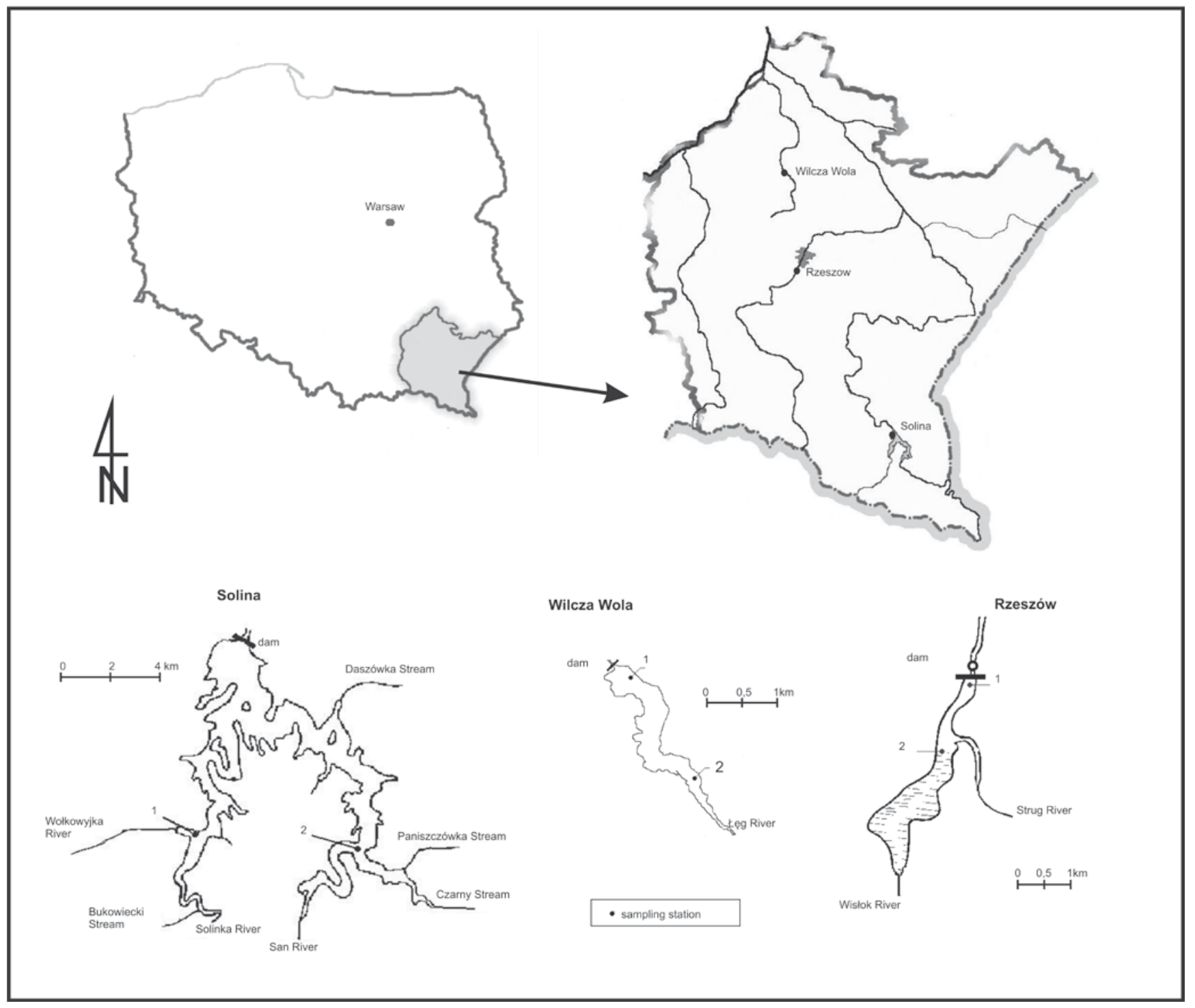

Fig. 1. Locations of the reservoirs in which gas fluxes have been studied. The sites are: the Solina Reservoir, Rzeszów Reservoir and Wilcza Wola Reservoir 
Table 1. Morphometric properties of the studied reservoirs (Tomaszek and Czerwieniec 2000)

\begin{tabular}{|l|c|c|c|c|c|}
\hline \multicolumn{1}{|c|}{ Reservoir/ Parameter } & $\begin{array}{c}\text { Volume } \\
\left(\mathrm{mln} \mathrm{m}^{3}\right)\end{array}$ & $\begin{array}{c}\text { Area } \\
\left(\mathrm{km}^{2}\right)\end{array}$ & Mean depth $(\mathrm{m})$ & $\begin{array}{c}\text { Maximum depth } \\
(\mathrm{m})\end{array}$ & $\begin{array}{c}\text { Mean residence } \\
\text { time }(\mathrm{days})\end{array}$ \\
\hline Solina & 502 & 22 & 22 & 60 & 215 \\
\hline Rzeszów & 1.1 & 1.18 & 0.5 & 6 & 2 \\
\hline Wilcza Wola & 4.2 & 1.6 & 2.6 & 30 & 36 \\
\hline
\end{tabular}

ing encroachment on to previously open surface water. Despite an attempt at reconstruction in 1996, the reservoir has mostly silted up (Tomaszek 1995). Furthermore, both of its tributaries, the rivers Wisłok and Strug, are highly polluted with nutrients, the drainage basin of here being mainly agricultural, with a few industrial centers.

The Wilcza Wola Reservoir is situated on the River Łęg. It was filled in 1988, having been mainly constructed for recreational purposes. Forestry prevails in the vicinity of this reservoir. The locations of the sampling stations for all the reservoirs studied are shown in Fig. 1.

\section{Gas sampling}

Gas samples were taken from the studied reservoirs in 2009 (see Table 2). The $\mathrm{CO}_{2}$ and $\mathrm{CH}_{4}$ fluxes were measured using a static chamber method. A stainless still chamber $(0.3 \mathrm{~m} \times 0.3 \mathrm{~m} \times 0.16 \mathrm{~m})$ equipped with a dry battery driven fan and a small vent stopped by silicon septum for sampling was used. Five gas samples from the chamber air headspace were manually withdrawn into gastight syringes at $0,10,20,30,40$ minutes after deployment. All samples were transported to the laboratory and analysed of gas concentration within $4 \mathrm{~h}$. The samples were analyzed using a Pye Unicam gas chromatograph (model PU-4410/19) equipped with a flame ionization detector (FID) and a stainless steel column packed with a Haye Sep Q, 80/100 Mesh, $6 \mathrm{ft}$ in length and of $2 \mathrm{~mm}$ ID. The GC was also equipped with a methanizer to detect low levels of carbon dioxide. The methanizer is packed with a nickel catalyst powder and heated to $380^{\circ} \mathrm{C}$. When the column effluent mixes with the FID hydrogen supply and passes through the methanizer, $\mathrm{CO}_{2}$ is converted to $\mathrm{CH}_{4}$. The carrier gas was helium at a flow rate of $30 \mathrm{cc} / \mathrm{min}$.

Gas fluxes were calculated from a linear regression with gas concentration change within the chamber versus time and expressed in $\mathrm{mmol} \mathrm{m}^{-2} \mathrm{~d}^{-1}$. Positive changes indicated emissions of gas from reservoir, while negative changes indicated its consumption.

\section{Results and discussion}

The results of the research are presented in $\mathrm{Ta}-$ ble 2 and Fig. 2.The reservoirs under investigations showed significant differences in their methane fluxes, which were calculated to range between 0 and over $240 \mathrm{mmol} \mathrm{m}^{-2} \mathrm{~d}^{-1}$ (Fig. 2). There was in fact no methane flux at all in the Solina Reservoir in either series (Fig. 2 , panel D). In contrast, the level of methane emission to the atmosphere from the Rzeszów Reservoir was very high. Furthermore, markedly higher fluxes were observed at both research stations in summer where air temperature was slightly more than $30^{\circ} \mathrm{C}$ and water temperatures at stations 1 and 2 were at about 24 and $22^{\circ} \mathrm{C}$ respectively. In autumn, when air temperature was at $5.5^{\circ} \mathrm{C}$ and water temperatures at 8 and $7^{\circ} \mathrm{C}$ respectively, methane fluxes were about 3.5 and 5.5 fold lower at the stations. These results probably indicate an interdependence between temperature and methane emission to the atmosphere. Such a relationship between temperature and methanogenesis is well documented (Dunfield et al. 1993; Zimov et al. 1997; Xing et al. 2005). Likewise and Xing et al. (2005) found that high algal activity during summer may affect methane emissions, since freshly produced organic matter supplies the substrate for methanogesesis.

One research series was also conducted for the Wilcza Wola Reservoir. There, station 1 (located at the bottom part of the reservoir) recorded a significantly lower methane flux than station 2 . The fluxes in station were at 1.95 and $28.22 \mathrm{mmol} \mathrm{m}^{-2} \mathrm{~d}^{-1}$ respectively. These values were nevertheless lower than these obtained for Rzeszów Reservoir at the same season.

During autumn the methane concentration in pore and surface water of the reservoirs was examined. Only in the Solina Reservoir was there methane neither in bottom sediments nor in surface water. Pore water from sediment in both the Rzeszów and Wilcza Wola Reservoirs was characterised by similar methane concentration (Table 2), though $\mathrm{CH}_{4}$ concentrations were significantly lower in surface water than in 


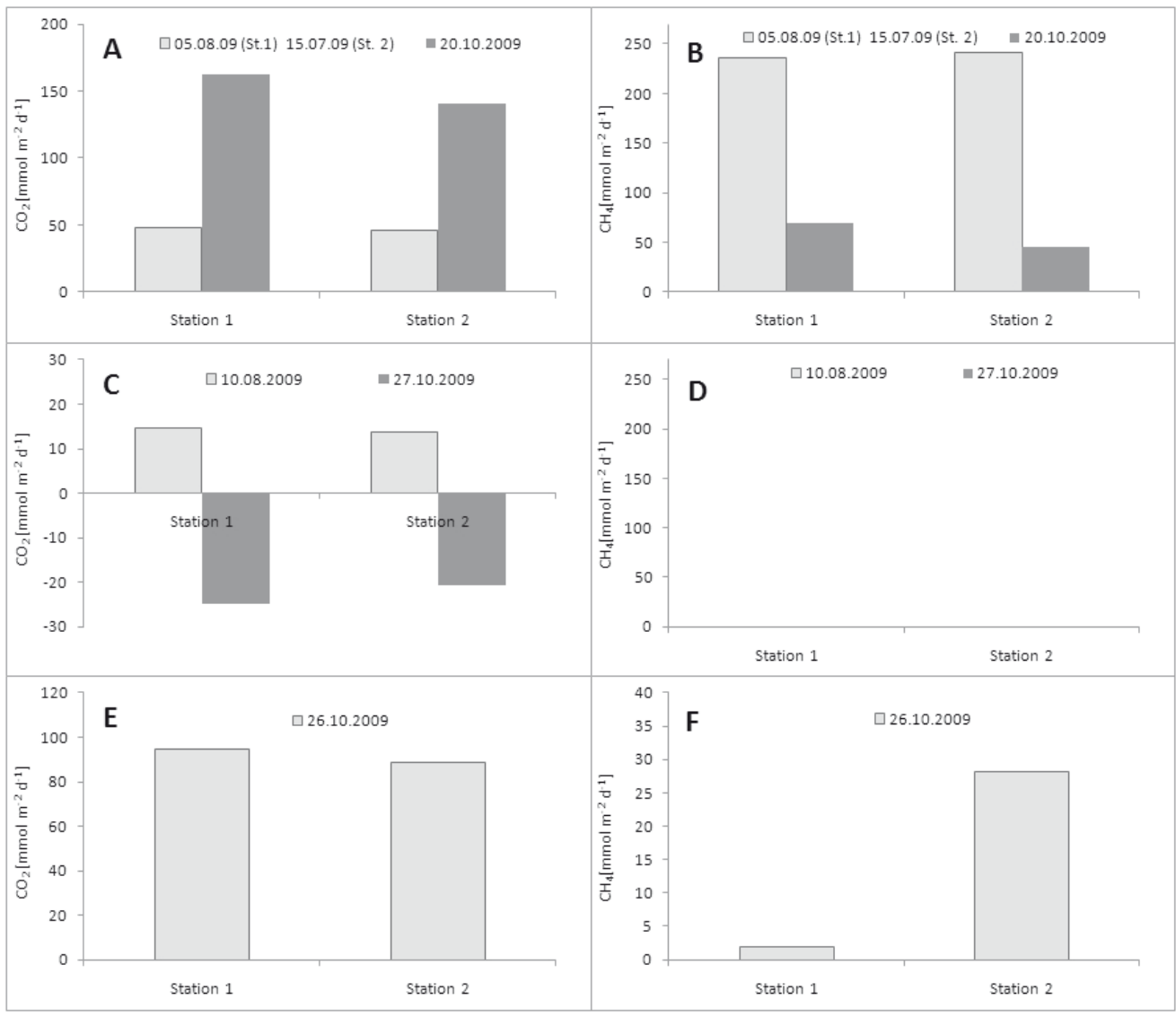

Fig. 2. Fluxes of $\mathrm{CH}_{4}$ and $\mathrm{CO}_{2}$ at the water-air interface of the reservoirs studied. Panels A, C, E - carbon dioxide fluxes from the Rzeszów, Solina and Wilcza Wola Reservoirs, respectively. Panels B, D, F - methane fluxes from the Rzeszów, Solina and Wilcza Wola Reservoirs, respectively

Table 2. Air and water temperature, concentration of oxygen, methane and carbon dioxide in water of the reservoirs studied

\begin{tabular}{|c|c|c|c|c|c|c|c|c|}
\hline \multirow{2}{*}{ Station } & \multirow{2}{*}{$\begin{array}{l}\text { Sampling } \\
\text { time }\end{array}$} & \multirow{2}{*}{$\begin{array}{l}\mathrm{T}_{\text {air }} \\
{\left[{ }^{\circ} \mathrm{C}\right]}\end{array}$} & \multirow{2}{*}{$\begin{array}{l}\mathrm{T}_{\text {water }} \\
{\left[{ }^{\circ} \mathrm{C}\right]}\end{array}$} & \multirow{2}{*}{$\begin{array}{c}\mathrm{O}_{2} \\
{\left[\mathrm{mg} \mathrm{l}^{-1}\right]}\end{array}$} & \multicolumn{2}{|c|}{$\begin{array}{c}\mathrm{CH}_{4} \\
{\left[\mu \mathrm{mol} \mathrm{I}^{-1}\right]}\end{array}$} & \multicolumn{2}{|c|}{$\begin{array}{c}\mathrm{CO}_{2} \\
{\left[\mu \mathrm{mol} \mathrm{I}^{-1}\right]}\end{array}$} \\
\hline & & & & & sediment & $\begin{array}{c}\text { surface } \\
\text { water }\end{array}$ & sediment & $\begin{array}{c}\text { surface } \\
\text { water }\end{array}$ \\
\hline \multicolumn{9}{|c|}{ Rzeszów Reservoir } \\
\hline \multirow{2}{*}{1} & 05.08 .2009 & 31 & 24.3 & 7.61 & n.m & n.m & n.m & n.m \\
\hline & 20.10 .2009 & 5.5 & 8 & 7.85 & 7.25 & 0.95 & 1118.34 & 876.54 \\
\hline \multirow{2}{*}{2} & 15.07 .2009 & 30 & 22.8 & 4.36 & n.m & n.m & n.m & n.m \\
\hline & 20.10 .2009 & 5.5 & 7 & 9.22 & 38.67 & 3.93 & 1181.33 & 913.09 \\
\hline \multicolumn{9}{|c|}{ Solina Reservoir } \\
\hline \multirow{2}{*}{1} & 10.08.2009 & 25 & 20.3 & 7.45 & n.m & n.m & n.m & n.m \\
\hline & 27.10 .2009 & 11 & 12 & 7.93 & n.d & n.d & 759.82 & 587.18 \\
\hline \multirow{2}{*}{2} & 10.08 .2009 & 25 & 20.5 & 7.74 & n.m & n.m & n.m & n.m \\
\hline & 27.10 .2009 & 11 & 12 & 8.40 & n.d & n.d & 761.73 & 608.73 \\
\hline \multicolumn{9}{|c|}{ Wilcza Wola Reservoir } \\
\hline 1 & 26.10 .2009 & 16 & 12 & 9.21 & n.d & n.d & 581.73 & 384.54 \\
\hline 2 & 26.10 .2009 & 16 & 12 & 8.58 & 37.33 & n.d & 703.20 & 398.84 \\
\hline
\end{tabular}

n.m, not measured n.d, not detected 
the bottom sediments. Taking into account the very good oxygen conditions in the water of the reservoirs (Table 2), it can be concluded that most of the methane produced in the sediment is oxidized in an upper (aerobic) bottom layer or water column, or else that diffusive methane flux is not the main transport mechanism taking this gas from the sediment into the atmosphere. The second possible explanation that methane diffusive fluxes are significantly lower at the sediment-overlying water interface than at the wateratmospheric air interface (Gruca-Rokosz et al. 2010). This indicated that ebullition may be the main pathway by which methane is transported from sediments into the atmosphere. These observations are consistent with the views of other researchers, who claim that the production and loss of gas bubbles is the main $\mathrm{CH}_{4}$ transport mechanism to the atmosphere in shallow reservoirs or lakes (Casper et al. 2000; Adams 2005; Huttunen et al. 2006).
The high values for methane emission obtained for the Wilcza Wola and Rzeszów Reservoirs are comparable with results cited for tropical reservoirs (Table 3). However, the fluxes obtained for the Rzeszów Reservoir are surprisingly high. In the other Polish dam reservoirs - Włocławek and Siemianówka - the methane release was 25.7 and $44.12 \mathrm{mmol} \mathrm{m}^{-2} \mathrm{~d}^{-1}$ respectively (Trojanowska and Kurasiewicz 2009). These authors considered such values high and comparable with those from waters in the tropical zone. Yet these values were only one fifth as high as the maximum values for the Rzeszów dam reservoir.

Carbon dioxide concentrations recorded from both pore and surface water of the studied reservoirs were significantly higher than methane concentrations (Table 2) and ranged from about 384 to about $1181 \mu \mathrm{mol} \mathrm{l}^{-1}$, however values obtained in surface water were lower than those in sediments. As in the case of methane, so again the highest carbon dioxide fluxes

Table 3. Methane and carbon dioxide fluxes to the atmosphere from various aquatic ecosystems

\begin{tabular}{|c|c|c|c|}
\hline Lake/Reservoir & $\begin{array}{c}\mathrm{CH}_{4} \\
{\left[\mathrm{mmol} \mathrm{m}^{-2} \mathrm{~d}^{-1}\right]}\end{array}$ & $\begin{array}{c}\mathrm{CO}_{2} \\
{\left[\mathrm{mmol} \mathrm{m}^{-2} \mathrm{~d}^{-1}\right]}\end{array}$ & Reference \\
\hline \multicolumn{4}{|c|}{ Temperate } \\
\hline Solina (Poland) & 0 & $-20.78-14.73$ & This study \\
\hline Rzeszów (Poland) & $45.98-240.61$ & $46.41-162.51$ & This study \\
\hline Wilcza Wola (Poland) & $1.99-28.22$ & $88.48-94.58$ & This study \\
\hline Mietków (Poland) & 0 & & Trojanowska, Kurasiewicz, 2009 \\
\hline Turawa (Poland) & 2.56 (average) & & Trojanowska, Kurasiewicz, 2009 \\
\hline Sulejów (Poland) & 2.87 (average) & & Trojanowska, Kurasiewicz, 2009 \\
\hline Włocławek (Poland) & 25.7 (average) & & Trojanowska, Kurasiewicz, 2009 \\
\hline Siemianówka (Poland) & 44.12 (average) & & Trojanowska, Kurasiewicz, 2009 \\
\hline Lanca do Po (Italy) & $27.9-116.3$ & $-60.5-448.5$ & Bolpagni et al. 2007 \\
\hline Priest Pot (U.K.) & $0.06-1.40$ & $3.9-102.00$ & Casper et al. 2000 \\
\hline ELARP (Canada) & $3.12-5.62$ & $25-84.1$ & Kelly et al. 1997 \\
\hline Average fluxes & $0.6-5$ & $17-70$ & St. Louis et al. 2000 \\
\hline \multicolumn{4}{|c|}{ Tropical } \\
\hline Samuel (Brazil) & 11.47 (average) & 183.8 (average) & dos Santos et al. 2006 \\
\hline Miranda (Brazil) & 16.4 (average) & 113.2 (average) & dos Santos et al. 2006 \\
\hline Tres Marias (Brazil) & 20.5 (average) & -3.23 (average) & dos Santos et al. 2006 \\
\hline Tucurui (Brazil) & 12.84 (average) & 237.1(average) & dos Santos et al. 2006 \\
\hline Serra da Mesa (Brazil) & 7.56 (average) & 30 (average) & dos Santos et al. 2006 \\
\hline Petot Saut (French Guyana) & $0.31-237.5$ & $13.2-238.6$ & Galy-Lacaux et al. 1997 \\
\hline Average fluxes & $1.25-94$ & $10-232$ & St. Louis et al. 2000 \\
\hline \multicolumn{4}{|c|}{ Subtropical } \\
\hline Donghu Lake (China) & $0.004-0.34$ & $-0.13-3.62$ & Xing et al. 2005 \\
\hline
\end{tabular}


are reported in Rzeszów Reservoir and the lowest ones at Solina.

Conversely, as in the case of methane, at the Rzeszów Reservoir, higher carbon dioxide fluxes to the atmosphere were observed in autumn and lower ones in summer. The negative correlation between a flux and a season (and thus a temperature) indicates that the activity of algae have a significant role to play in the flow of carbon dioxide into the atmosphere (Huttunen 2003). The high primary production in summer may reduce carbon dioxide emission to the atmosphere through algal $\mathrm{CO}_{2}$ fixation. Most of this carbon incorporated into organic matter is later decomposed and returned to the atmosphere, however. In eutrophic waterbodies like the Rzeszów Reservoir (Koszelnik et al.2004), relatively large quantities of decomposed organic carbon fixed by photosynthesis are recycled as methane (St. Louis et al. 2000).

Summer carbon dioxide emission from Solina was only at a level one third as high as that in Rzeszów Reservoir in the same time. In autumn, absorption of carbon dioxide was observed at Solina. The autumnal nature of this phenomenon was probably associated with water temperature reductions, and thus with an increase in gas solubility in water. Carbon dioxide emission to the atmosphere from the Wilcza Wola Reservoir was relatively high, but still only approximately half the emission recorded in the corresponding period for the Rzeszów Reservoir.

Carbon dioxide fluxes obtained for Solina Reservoir may be comparable with values characteristic for temperate-zone reservoirs. The $\mathrm{CO}_{2}$ fluxes for Rzeszów and Wilcza Wola Reservoirs, like those for methane, are comparable to the results quoted for large reservoirs in the tropics.

\section{Acknowledgments}

The study was supported by Poland's Ministry of Science, via grant no. N N305 077836.

\section{References}

Adams D. D., 2005, Diffuse flux of greenhouse gases methane and carbon dioxide - at the sediment-water interface of some lakes and reservoirs of the world, [in:] Tremblay, A., Varfalvy, L., Roehm, C., Garneau, M. (eds.), Greenhouse gas emissions - fluxes and processes. Hydroelectric reservoirs and natural environments, Springer, Berlin Heidelberg: 129-153.
Adams D. D., Baudo R., 2001, Gases $\left(\mathrm{CH}_{4}, \mathrm{CO}_{2}\right.$ and $\left.\mathrm{N}_{2}\right)$ and pore water chemistry in the surface sediments of Lake Orta, Italy: acidification effects on $\mathrm{C}$ and $\mathrm{N}$ gas cycling, J. Limnol. 60(1): 79-90.

Bolpagni R., Pierobon E., Bartoli M., Nizzoli D., Tomaselli M., Viaroli P., 2007, Methane and carbon dioxide wateratmosphere daily exchanges in an oxbow lake with a Trapa natans stand, Aquat. Bot. 87: 43-48.

Casper P., Maberly S. C., Hall G. H., Finlay B. J., 2000, Fluxes of methane and carbon dioxide from a small productive lake to the atmosphere, Biogeochemistry 49: 1-19.

Dos Santos M. A., Rosa L. P., Sikar B., Sikar E., dos Santos E. O., 2006, Gross greenhouse gas fluxes from hydro-power reservoir compared to thermo-power plants, Energ. Policy 34: 481-488.

Dunfield P., Knowles R., Dumont R., Moore T. R., 1993, Methane production and consumption in temperate and subarctic peat soils: response to temperature and pH, Soil Biol. Biochem. 25: 321-326.

Galy-Lacacaux C., Delmas R., Jambert C., Dumestre J-F., Labroue L., Richard S., Gosse P., 1997, Gaseous emissions and oxygen consumption in hydroelectric dams: a case study in French Guyana, Global Biogeochem. Cy. 11: 471-483.

Gruca-Rokosz R. Tomaszek J. A., Koszelnik P., Czerwieniec E., 2010, Methane and carbon dioxide fluxes at the sediment-water interface in some reservoirs in SE Poland, Pol. J. Environ. Stud. (in press).

Haese R. R., Meile C., van Cappellen P., de Lange G. J., 2003, Carbon geochemistry of cold seeps: Methane fluxes and transformation in sediments from Kazan mud volcano, eastern Mediterranean Sea, Earth Planet. Sc. Lett. 212: 361-375.

Huttunen J. T, Alm J., Liikanen A., Juutinen S., Larmola T., Hammar T., Silvola J., Martikainen P. J., 2003, Fluxes of methane, carbon dioxide and nitrous oxide in boreal lakes and potential anthropogenic effects on the aquatic greenhouse gas emissions, Chemosphere 52: 609-621.

Huttunen J. T., Väisänen T. S., Hellsten S. K., Mertikainen P. J., 2006, Methane fluxes at the sediment - water interface in some boreal lakes and reservoirs, Boreal Env. Res. 11: 27-34.

Kelly C. A., et al., 1997, Increases in fluxes of greenhouse gases and methyl mercury following flooding of an experimental reservoir, Environ. Sci. Technol. 31: 13341344.

Koszelnik P., Tomaszek J., Sokół Z., Kryczka R., 2004, Charakterystyka zbiornika zaporowego w Rzeszowiepo trzydziestu latach eksploatacji (Characteristics of the reservoir in Rzeszów City after thirty years of exploitation), Proceedings of V Conference: „Protection and reclamation of lakes", Grudziądz: 111-120 (in Polish).

Krithika R., Purvaja R., Ramesh R., 2008, Fluxes of methane and nitrous oxide from an Indian mangrove, Curr. Sci. 94(2): 218-224. 
Matthews C. J. D., Joyce E. M., St. Louis V. L., Schiff S. L., Venkiteswaran J. J., Hall B. D., (drew) Bodaly R. A., Beaty K., G., 2005, Carbon dioxide and methane production in small reservoirs flooding upland boreal forest, Ecosystems 8: 267-285.

Rastogi M., Singh S., Pathak H., 2002, Emission of carbon oxide in soil, Curr. Sci. 82(5): 510 -517.

Søvik A. K., Kløve B., 2007, Emission of $\mathrm{N}_{2} \mathrm{O}$ and $\mathrm{CH}_{4}$ from a constructed wetland in southeastern Norway, Sci. Total Environ. 380: 28-37.

St. Louis V. L., Kelly C. A., Duchemin E., Rudd J. W. M., Rosenberg D. M., 2000, Reservoir surfaces as sources of greenhouse gases to the atmosphere: a global estimate, BioScience 50(9): 766-775.

Tomaszek J.A., 1995, Ochrona i rekultywacja zbiornika zaporowego w Rzeszowie (Protection and reclamation of Rzeszów Reservoir), Proceedings of XVI Symposium of Polish Committee IAWQ, Zabrze: 133-150 (in Polish).

Tomaszek J. A., Czerwieniec E., 2000, In situ chamber denitrification measurements in reservoir sediments: an example from southeast Poland, Ecol. Eng. 16: 61-71.
Trojanowska A., Kurasiewicz M., 2009, Potencjał metanogeniczny osadów wybranych zbiorników zaporowych w Polsce (Methanogenic potential of sediments in selected Polish dam reservoirs), [in:] W. Marszelewski (ed.), Anthropogenic and natural transformations of lakes. Vol. 3, PTLim, Toruń: 229-234 (in Polish).

Wilcock R. J., Sorrell B. K., 2008, Emission of greenhouse gases $\mathrm{CH}_{4}$ and $\mathrm{N}_{2} \mathrm{O}$ from low-gradient streams in agriculturally developed catchments, Water Air Soil Poll. 188: 155-170.

Xing Y., Xie P, Yang H., Ni L., Wang Y., Rong K., 2005, Methane and carbon dioxide fluxes from a shallow hypereutrophic subtropical Lake in China, Atmos. Environ. 39: 5532-5540.

Zimov S. A., Voroaev Y. V., Semiletov I. P, Davidov S. P., Prosiannikov S. F., Chapin III F. S., Chapin M. C., Trumbore S., Tyler S., 1997, North Siberian Lakes: a methane source fueled by Pleistocene carbon, Science 227: 800-802. 